\title{
Adaptation of cyanobacteria and microalgae to extreme environmental changes derived from anthropogenic pollution
}

\author{
V. López-Rodas, E. Maneiro \& E.Costas \\ Departamento de Producción Animal (Genética). Facultad de Veterinaria. Universidad Complutense. \\ 28040. Madrid. Spain \\ Corresponding author: V. López-Rodas (vlrodas@vet.ucm.es)
}

\begin{abstract}
Nowadays are living in a global extinction period consequence of human activities that are altering biosphere-level processes. Microalgal populations are being exposed to by-products of human activities for the first time and little is known about their mechanisms of adaptation. Cyanobacteria and microalgae could to adapt to novel environments through selection on spontaneous mutations or through individual responses (i.e. resistant organisms arising by mutations occurring randomly prior to selective agent exposure or by direct and specific adaptation in response to selective agent). We are working on mechanisms of adaptation of these organisms to catastrophic environmental changes coming from residual materials of water pollution. Fluctuation analysis is the procedure to study this adaptive process. Cyanobacteria and microalgal species exposed to several pollutants (herbicides, antibiotics, heavy metals, sulphureous waters and others) showed resistant variants arise from rare spontaneous pre-selective mutations occurring prior to pollutant exposition. Spontaneous mutations seem to be enough to assure the adaptation of large microalgal populations. However, resistant mutants show diminished growth and photosynthesis.
\end{abstract}

Keywords: Adaptation, cyanobacteria, environmental change, fluctuation test, microalgae, mutation, pollution.

\begin{abstract}
RESUMEN
Estamos en un periodo de extinción global consecuencia de las actividades humanas y que están alterando los procesos de la biosfera. Las poblaciones de microalgas estan siendo expuestas por primera vez a estos productos fruto de la actividad antropogénica y sus mecanismos de adaptación son muy poco conocidos. Las cianobacterias y microalgas pueden adaptarse a nuevas condiciones ambientales a través de mutaciones espontáneas o a través de respuestas individuales (p.e. los organismos resistentes se pueden producir por mutaciones que ocurren antes de la exposición al agente selectivo, o por una respuesta específica y directa al contaminante). Nosotros hemos trabajado en los mecanismos de adaptación de estos organismos al cambio ambiental brusco debido a contaminantes del agua. El análisis de fluctuación es el procedimiento adecuado para el estudio del proceso adaptativo. Las especies de cianobacterias y microalgas expuestas a distintos contaminantes (herbicidas, antibióticos, metales pesados, aguas sulfurosas y otros...) muestran variantes resistentes que se producen por raras mutaciones espontáneas que ocurren antes de la exposición al contaminante. Estos mutantes resistentes mostraron una disminución del crecimiento y de la fotosíntesis respecto a la población sensible. Las mutaciones espontáneas pueden ser suficientes para asegurar la adaptación en las enormes poblaciones de microalgas.
\end{abstract}

Palabras clave: Adaptación, cianobacterias, cambio ambiental, análisis de fluctuación, microalgas, mutación, contaminación.

\section{THE PROBLEM}

Nowadays, we are living in a geological instant in which global extinction rates are 50-500 times background and are increasing due to those human activities that are altering biosphere-level processes. It is supposed that several million populations and 300-30,000 species go extinct annually from a total of $>10$ million species (Woodruff 2001). Even, humans have transform- ed aquatic ecosystems implementing massive loss of diversity by pollution. Distinctive features of biosphere future could include a homogenization of biotas, a proliferation of opportunistic species, a pest-and-weed ecology, and unpredictable emergent novelties (Myers and Knoll 2001). The biodiversity crisis is reasonably understood for terrestrial vertebrates and a few other groups, but little is known about organisms as abundant and important as microbes. Studies in bacteria 
Set 1

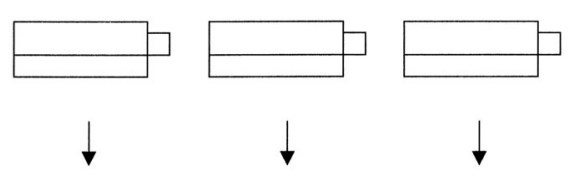

Propagation of cultures

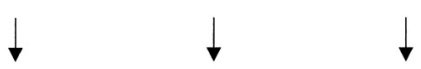

Addition of selective medium

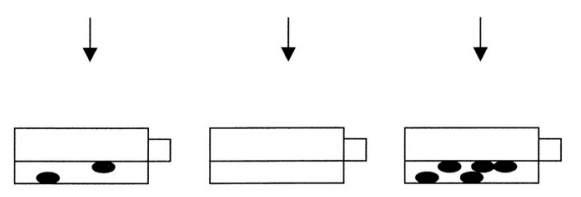

Set 2

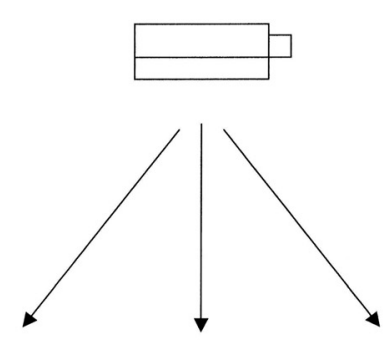

Transfer to selective medium

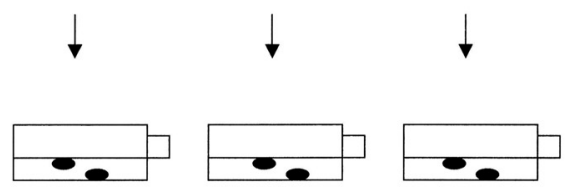

Figure 2. Modified Luria-Delbrück fluctuation analysis. Set 1 examined the fluctuation of mutational events in different cultures (each started from a small inoculum) propagated under non-selective conditions and finally supplemented with liquid medium containing the selective agent. In this example, a mutational event occurred late in the propagation of culture 1 and early in the propagation of culture 3; no mutational events occurred in culture 2. Set 2 control sampled the variance of parental populations. Análisis de fluctuación de Luria-Delbrück modificado. El set 1 muestra la fluctuación de las mutaciones en cultivos diferentes (cada uno proviene de un inóculo pequeño) creciendo bajo condiciones no selectivas y añadiendo al final el agente selectivo en medio líquido. En este ejemplo, una mutación ocurre tarde en el cultivo 1 y temprano en el cultivo 3 y no ocurre ninguna mutación en el cultivo 2. El set 2 sirve como control de la varianza de las poblaciones parentales.

and protists seem interesting, as dependable nutrient cycles may become less predictable as essential microbes succumb to anthropogenic toxins (Woodruff, 2001). Since microalgae and cyanobacteria are the principal primary producers of aquatic ecosystems (Falkowski \& Raven, 1997), the tolerance of these organisms to contaminated environments is relevant from an ecological point of view. However, little is known about the mechanisms allowing algal adaptation to such extreme conditions. More investigation is needed to make sound predictions about the future, and to determine actions to mitigate the biodiversity crisis (Ehrlich, 2001).

The problem of whether microorganisms adapt to novel environments through selection on spontaneous mutations or through individual responses has an interesting history in biology (reviewed by Sniegowsky \& Lensky, 1995; Sniegowsky, 2005). The neo-Darwinian view that evolutionary adaptation occurs by selection on pre-existing genetic variation was early accepted for multicellular organisms. In contrast, many biologists felt that adaptation in bacteria -and perhaps in other microorganisms- may be a different, nonDarwinian process (review by Lewis, 1934; Huxley, 1942, Sniegowsky, 2005).

Under a classic neo-Darwinist point of view, genetic variability maintained in natural populations previously to an environmental change is considerate as the pacemaker of adaptation in changing environments (Lewontin 1974). In contrast, recent evolutionary studies in bacterial populations suggest new hypothesis, including adaptive mutations (i.e. a process that, during no lethal selections, produces mutations that relieve the selective pressure whether or not other, no selected mutations, are also produced) resembling Lamarckism (Cairns et al., 1988, Foster, 2000). The key to resolve this debate is to know the pre-adaptive or post-adaptive origin of new mutations, because adaptive evolution ultimately depends on the origin of new mutations (Sniegowsky 2005). Surprisingly, however, there almost no studies that have made a direct experimental connection between the rates of 
origin of favored mutants and the process of adaptation due to practical and theoretical difficulties (Sniegowsky 2005).

In this sense, we are working on mechanisms of adaptation of cyanobacteria and microalgae subsequent to sudden and catastrophic environmental changes coming from novel residual materials of water pollution, and to extreme natural environments. Our work integrates approaches from evolutionary ecology, genetics and phycology to connect mutation and adaptation in these organisms.

\section{THE PROCEDURES}

\section{Theory}

In a seminal paper, Luria \& Delbrück (1943) introduced fluctuation analysis as a combined experimental and statistical methodology for distinguishing whether microorganisms adapt to novel environments through selection on spontaneous mutations or through individual responses (i.e. pre-adaptive or post-adaptive origin of new mutations). To conduct a fluctuation test, multiple independent cultures of the cells of interest are grown in a nonselective medium from a small inoculum to some common final population size. Subsequently the cultures are exposed to the selective agent that kills sensitive cells. Afterwards the resistant cells remaining in each culture are then counted. Two distinct results can be obtained:

i) If resistant cells arise only by spontaneous mutation previously to selection, then there should be a high variance in their number per culture (fluctuation). This is because spontaneous mutation occurs by chance, and consequently, some cultures wild have acquired resistant mutants early in their history, whereas other cultures will have acquired resistant mutants late or not at all.

ii) If resistant cells arise only in response to the selective medium, then their distribution per culture should be more uniform (without fluctuation), reflecting a low but constant probability that each cell will respond with resistance.
Statistically, spontaneous mutation thus predicts a high variance to mean ratio (coefficient of variation $>1$ ) in the number of resistant cells among cultures, whereas resistance acquired in response to exposure predicts a coefficient of variation that is approximately 1 , as expected from the Poisson distribution.

\section{Practice}

In the classical Luria-Delbrück fluctuation test, resistant cells are enumerated by spreading cultures separately on selective agar plates. Cyanobacteria and microalgae however, does not grow well on agar media. So, we developed a fluctuation test (summarized in Fig. 1) entirely in liquid medium, growing algal cultures first in a benign medium and then exposing them to selective agent (Costas et al., 2001; Lopez-Rodas et al., 2001). All cultures initially collapsed after exposure to selective agent, but some re-grew after many days, due to the growth of resistant cells. The number of these resistant cells in each culture is counted under the microscope. As a control for this liquid fluctuation test we exposed multiple aliquots of a single large algal culture to selective agent. These aliquots contained the same number of cells as the fluctuation test cultures (Luria \& Delbrück also employed a similar control in their original experiment).

On the hypothesis that adaptation to selective agent occurs by selection on spontaneous mutation, the controls should have had a low coefficient of variation (consistent with the error in sampling resistant cells from one large culture). In contrast, the fluctuation test cultures (Set 1) should have a high coefficient of variation.

In addition, the proportion of cultures showing no mutant in the first set of experiments is used to estimate the mutation rate $\left(\mathrm{P}_{0}\right.$ estimator $)$ as follow:

$\mathrm{P}_{0}=\mathrm{e}^{-\mu(\mathrm{Nt}-\mathrm{N} 0)}($ Luria \& Delbrück, 1943)

where, $\mathrm{P}_{0}$ is the proportion of cultures showing no mutant colonies after plating; $\mu$ is the mutation rate; $\mathrm{N}_{0}$ is the initial cell population size; $\mathrm{N}_{\mathrm{t}}$ is the final cell population size. 


\section{SOME ANSWERS}

During the last five years, we have analyzed adaptation of cyanobacteria and microalgae to numerous anthropogenic pollutants (herbicides, antibiotics, heavy metals, and others) as well as to extreme natural environments (sulphureous waters from La Hedionda, Casares, Málaga; Tinto River, Huelva) as previously described (Costas et al., 2001; López-Rodas et al., 2001; Baos et al., 2002; García-Villada et al., 2002, 2004; Altamirano et al., 2004; Flores-Moya et al., 2005).

Cyanobacteria and microalgae (which are the principal primary producers of aquatic ecosystems, Fallowsky \& Raven 1997) are being exposed to by-products of human technology for the first time. Consequently, the tolerance of these organisms to stressed environments is an import subject because carrying an ecological cost.
How these photosynthetic microorganisms are able to succeed in polluted and extreme environments? To respond this question we need to know:

i) The mechanisms (classic NeoDarwinian explanations based on selection on spontaneous mutations, or through individual responses resembling Lamarckism) that allows this adaptation.

ii) The rate of adaptation (i.e. mutation rates from pollutant sensitivity to pollutant resistance).

iii) The cost, in terms of fitness, growth rates, photosynthetic efficiency, and others, of this adaptation.

When microalgal cultures are treated with a contaminant, the cultures collapse due to destruction of sensitive cells by the contaminant. However, after further incubation for several

Table 1. Fluctuation test in diverse cyanobacteria and microalgal species exposed to anthropogenic pollutants and extreme environments. Análisis de fluctuación en distintas especies de cianobacterias y microalgas expuestas a contaminantes antropogénicos y a ambientes extremófilos

\begin{tabular}{|c|c|c|c|c|c|}
\hline \multirow[b]{2}{*}{$\begin{array}{l}\text { ANTROPHOGENIC } \\
\text { POLLUTION }\end{array}$} & \multirow[b]{2}{*}{ Organism } & \multicolumn{2}{|c|}{ Fluctuation test } & \multirow[b]{2}{*}{$\begin{array}{l}\text { Mutation } \\
\text { rate }\end{array}$} & \multirow[b]{2}{*}{ Source } \\
\hline & & $\begin{array}{l}\text { CV } \\
\text { Set1 }\end{array}$ & $\begin{array}{l}\text { CV } \\
\text { Set } 2\end{array}$ & & \\
\hline $\begin{array}{l}\text { DCMU } \\
\text { 3-(3,4 dichloro- } \\
\text { phenyl)-1,1 } \\
\text { dimethylurea }\end{array}$ & $\begin{array}{c}\text { Dictyosphaerium chlorelloides }{ }^{1} \\
\text { Pseudanabaena planktonica }^{2} \\
\text { Dunaliella tertiolecta }\end{array}$ & $\begin{array}{l}>50 \\
>50 \\
>100\end{array}$ & $\begin{array}{l}0.7 \\
0.9 \\
0.7\end{array}$ & $\begin{array}{l}2.1 \times 10^{-6} \\
2.4 \times 10^{-6} \\
3.6 \times 10^{-6}\end{array}$ & $\begin{array}{l}\text { Costas et al. } 2001 \\
\text { López Rodas et al. } 2001 \\
\text { López Rodas et al. } 2001\end{array}$ \\
\hline Glyphosate & Microcystis aeruginosa $^{2}$ & $>50$ & 0.9 & $3.6 \times 10^{-7}$ & unpublished \\
\hline Erythromycin & Pseudanabaena planktonica $^{2}$ & 44 & 0.9 & $2.1 \times 10^{-6}$ & López Rodas et al. 2001 \\
\hline $\begin{array}{c}\text { TNT } \\
\text { Trinitrotoluene }\end{array}$ & $\begin{array}{c}\text { Scenedesmus } \mathrm{sp}^{1} \\
\text { Dictyosphaerium chlorelloides }\end{array}$ & $\begin{array}{c}>100 \\
32\end{array}$ & $\begin{array}{c}1.1 \\
0.85\end{array}$ & $\begin{array}{l}8.2 \times 10^{-6} \\
1.4 \times 10^{-5}\end{array}$ & $\begin{array}{l}\text { López Rodas et al. } 2001 \\
\text { García Villada et al. } 2002\end{array}$ \\
\hline Formaldehyde & Dictyosphaerium chlorelloides 1 & 39 & 0.9 & $3.5 \times 10^{-6}$ & unpublished \\
\hline Copper sulphate & Microcystis aeruginosa $^{2}$ & $>50$ & 1 & $1.76 \times 10^{-6}$ & García Villada et al. 2004 \\
\hline Aznalcollar mine spill & Scenedesmus intermedius ${ }^{1}$ & $>100$ & 1.2 & $2.12 \times 10^{-5}$ & Baos et al. 2002 \\
\hline $\begin{array}{c}\text { EXTREME } \\
\text { ENVIRONMENTS }\end{array}$ & Organism & $\begin{array}{l}\text { Fluctu } \\
\text { CV } \\
\text { Set1 }\end{array}$ & $\begin{array}{l}\text { on test } \\
\text { CV } \\
\text { Set } 2\end{array}$ & $\begin{array}{l}\text { Mutation } \\
\text { rate }\end{array}$ & Source \\
\hline $\begin{array}{c}\text { Hedionda spa } \\
\text { (sulphureous waters) }\end{array}$ & Spirogyra insignis ${ }^{1}$ & $>50$ & 0.8 & $2.7 \times 10^{-7}$ & Flores Moya et al. 2005 \\
\hline Tinto river (acid waters) & Dictyosphaerium chlorelloides 1 & 48 & 1.1 & $1.8 \times 10^{-6}$ & unpublished \\
\hline $\begin{array}{l}\text { 1.- Chlorophyceae } \\
\text { 2.- Cyanoprokaryota }\end{array}$ & & & & & \\
\hline
\end{tabular}


days, some cultures sometimes increase in density again, due to growth of algal variants that are resistant to the action of the contaminant. The key to understanding adaptation of microalgae is to analyze these rare algal variants that occurs after the massive destruction of the sensitive cells by the contaminant. Fluctuation analysis is the procedure to study the nature of adaptive process (i.e. resistant organisms arising by direct and specific adaptation in response to selective agent versus resistant organisms arise by rare spontaneous mutations occurring randomly prior to selective agent exposure).

Table 1 shows the fluctuation test in diverse microalgal species exposed to anthropogenic pollutants and extreme environments. The variation in Set 2 controls (variance/mean $\approx 1$ ) is consistent with Poisson variability in all the cases, indicating that any large fluctuations in Set 1 must be due to processes other than sampling error. In all Set 1 experiments the variance significantly exceeded the mean, indicating that resistant organisms arose by rare spontaneous mutation and not through direct and specific adaptation in response to environmental change. Adaptation of algal populations to modern pollution-derived environmental hazards (or extreme natural environments) seems to be the result of a rare event: the spontaneous mutation from sensitivity to resistance that occurs randomly prior to the cells come in contact with that contaminant.

Usually, spontaneous mutation rates in different organisms from bacteria to men are: i) exceedingly low, ii) vary considerably in different organisms, and iii) vary from gene to gene within the same species (review by Klug and Cummings, 1997). The rate of spontaneous mutation from sensitivity to resistance $(\mu)$ in the analysed microalgae exposed to anthropogenic and natural stressed environments were also low. These rates can vary inter-species exposed to same selective agent (i.e. $2.4 \times 10^{-6}$ mutants per cell division for DCMU-resistance in $P$. planktonica and $3.6 \times 10^{-6}$ mutants per cell division for DCMU-resistance in D. tertioleta), but do not change intra-species exposed to different selective agent (i.e. $2.4 \times 10^{-6}$ mutants per cell division for DCMU and $2.2 \times 10^{-6}$ mutants per cell division for erythromycin in P. planktoni$c a$ ). Spontaneous mutation rate in cyanobacteria was two orders of magnitude higher than the mutation rates observed in other prokaryotes $\left(\approx 10^{-8}\right)$ and similar to those of genes of several plants (i.e. maize) (Klug and Cummings, 1997). However, mutation for resistance seems to involve an important biological cost. All resistant

Table 2. Allelic frequency of the resistant mutant determined by the balance of the mutation rate and the rate of selective elimination. Frecuencia alélica del mutante resistente, determinada por el equilibrio entre la tasa de mutación y el coeficiente de selección.

\begin{tabular}{|c|c|c|c|c|}
\hline $\begin{array}{l}\text { ANTROPHOGENIC } \\
\text { POLLUTION }\end{array}$ & Organism & $\begin{array}{l}\text { Mutation } \\
\text { rate }\end{array}$ & $\begin{array}{l}\text { Coefficient of } \\
\text { selection }\end{array}$ & $\begin{array}{l}\text { Resistant-mutant } \\
\text { allele frequency }\end{array}$ \\
\hline $\begin{array}{l}\text { DCMU } \\
3-(3,4 \text { dichloro- } \\
\text { phenyl)-1,1 } \\
\text { dimethylurea }\end{array}$ & $\begin{array}{l}\text { Dictyosphaerium chlorelloides } \\
\text { Pseudanabaena planktonica } \\
\text { Dunaliella tertiolecta }\end{array}$ & $\begin{array}{l}2.1 \times 10^{-6} \\
2.4 \times 10^{-6} \\
3.6 \times 10^{-6}\end{array}$ & $\begin{array}{l}0.46 \\
0.84 \\
0.80\end{array}$ & $\begin{array}{l}2.1 \times 10^{-3} \\
1.6 \times 10^{-3} \\
2.1 \times 10^{-3}\end{array}$ \\
\hline Glyphosate & Microcystis aeruginosa & $3.6 \times 10^{-7}$ & 0.83 & $6.5 \times 10^{-4}$ \\
\hline Erythromycin & Pseudanabaena planktonica & $2.1 \times 10^{-6}$ & 0.82 & $1.6 \times 10^{-3}$ \\
\hline TNT & Scenedesmus sp & $8.2 \times 10^{-6}$ & 0.83 & $3.1 \times 10^{-3}$ \\
\hline Trinitrotoluene & Dictyosphaerium chlorelloides & $1.4 \times 10^{-5}$ & 0.40 & $5.9 \times 10^{-3}$ \\
\hline Copper sulphate & Microcystis aeruginosa & $1.7 \times 10^{-6}$ & 0.76 & $1.5 \times 10^{-3}$ \\
\hline Aznalcollar mine spill & Scenedesmus intermedius & $2.1 \times 10^{-5}$ & 0.49 & $6.5 \times 10^{-3}$ \\
\hline
\end{tabular}


mutants showed a diminished growth rates and photosynthetic performance compared to those of sensitive wild type (Table 2). Consequently, most of these mutants disappear sooner or later due to natural selection or chance but new resistant mutants arise in each generation (Spiess, 1989). At any one time there will be a certain number of resistant organisms that are not yet eliminated. The average number of such mutants will be determined by the balance of the mutation rate and the rate of selective elimination as:

$$
\mathrm{q}=\sqrt{(\mu / \mathrm{s})}
$$

where: $\mathrm{q}$ is the allele frequency of the mutant; $\mu$ is the mutation rate; and $s$ is the selection coefficient of the mutant (Ayala \& Kiger 1984). Such fraction of resistant mutants are presumably enough to assure the adaptation of microalgal populations to catastrophic water contamination and extreme environments, since the natural populations of microalgae are composed of abundant cell number (probably at least billions) and they are able to grow rapidly.

As conclusion, and employing the 'Occam's razor', spontaneous pre-selective mutants (as 'hopeful monsters') are enough to assure the adaptation of the extra large sized microalgal populations to catastrophic environmental changes. However, resistant mutants show reduced growth and photosynthesis, and although microalgal populations are able to survive to catastrophic events of contamination via spontaneous mutation, important ecological parameters (such as primary production, biomass) could be severely diminished.

\section{ACKNOWLEDGEMENTS}

Supported by Spanish DGI CGL 2005-01938/BOS, DGI CGL 2004 -02701/HID, and MAM/2484/2002.

\section{REFERENCES}

ALTAMIRANO, M., L. GARCÍA-VILLADA, M. AGRELO, L. SÁNCHEZ-MARTÍN, L. MARTÍNOTERO, A. FLORES-MOYA, M. RICO, V.
LÓPEZ-RODAS, \& E. COSTAS. 2004. A novel approach to improve specificity of algal biosensors using wild-type and resistant mutants: an application to detect TNT. Biosensors and Bioelectronics, 19: 1319-1323.

AYALA F. J. Y J. A. KIGER., 1984. Genética moderna. Ediciones Omega, Barcelona, España. 836 pp. BAOS, R., L. GARCÍA-VILLADA, M. AGRELO, V. LÓPEZ-RODAS, F. HIRALDO \& E. COSTAS. 2002. Short-term adaptation of microalgae in highly stressful environments: An experimental model analysing the resistance of Scenedesmus intermedius (Chlorophyceae) to the heavy metals mixture from the Aznalcóllar mine spill. European Journal of Phycology, 37: 593-600.

CAIRNS, J., J. OVERBAUGH \& S. MILLER. 1998. The origin of mutants. Nature, 335: 142-145.

COSTAS, E., E. CARRILLO, L. M. FERRERO, M. AGRELO, L. GARCÍA-VILLADA, J. JUSTE \& V. LÓPEZ-RODAS. 2001. Mutation of algae from sensitivity to resistance against environmental selective agents: The ecological genetics of Dictyosphaerium chlorelloides (Chlorophyceae) under lethal doses of 3-(3,4-dichlorophenyl)-1,1dimethylurea herbicide. Phycologia, 40: 391-398.

EHRLIRCH, P. R. 2001. Intervening in evolution: ethics and actions. Proc. Nat. Acad. Sci. USA., 98: 5477-5480.

FALKOWSKI, P. G. \& J. A. RAVEN . 1997. Aquatic photosynthesis. Malden, MA: Blackwell Science. $384 \mathrm{pp}$.

FLORES-MOYA, A., E. COSTAS, E. BAÑARES ESPAÑA, L. GARCÍA VILLADA, M. ALTAMIRANO \& V. LÓPEZ-RODAS. 2005. Adaptation of Spirogyra insignis (chlorophyta) to an extreme natural environment (sulphureous waters) through preselective mutations. New Phytologist, 166: 655-661.

FOSTER P. L. 2000. Adaptive mutation: Implications for evolution. BioEssay,s 22: 1067-1074.

GARCÍA-VILLADA, L., V. LÓPEZ-RODAS, E. BAÑARES-ESPAÑA, A. FLORES-MOYA, M. AGRELO, L. MARTÍN-OTERO \& E. COSTAS. 2002. Evolution of microalgae in highly stressing environments: An experimental model analyzing the rapid adaptation of Dictyosphaerium chlorelloides (Chlorophyceae) from sensitivity to resistance against 2,4,6-trinitrotoluene by rare preselective mutations. Journal of Phycology, 38: 1074-1081.

GARCÍA-VILLADA, L., M. RICO, M.ALTAMIRANO, L. SÁNCHEZ-MARTÍN, V. LÓPEZ-RODAS $\&$ E. COSTAS. 2004. Occurrence of copper resis- 
tant mutants in the toxic cyanobacteria Microcystis aeruginosa: Characterization and future implications in the use of copper sulphate as an algaecide. Water Research, 38: 2207-2213.

HUXLEY, J. 1942. Evolution: the modern synthesis. New York. USA. Harper. 705 pp.

KLUG, W. \& M. R. CUMMINGS. 2003. Concepts of genetics. $7^{\text {th }}$ ed. Prentice-Hall, Englewood Cliffs, NJ. 814 pp.

LEWIS I. M. 1934. Bacterial variation with special reference to behavior of some mutable strains of colon bacteria in synthetic media. Journal of Bacteriology, 28: 619-638.

LEWONTIN, R. C. 1974. The genetic basis of evolutionary change. Columbia University Press, New York. 346 pp.

LÓPEZ-RODAS, V., M. AGRELO, E. CARRILLO, L. M. FERRERO, A. LARRAURI, L. MARTÍNOTERO \& E. COSTAS. 2001. Resistance of microalgae to modern water contaminants as the result of rare spontaneous mutations. European Journal of Phycology, 36: 179-190.

LURIA, S. E. \& M. DELBRÜCK. 1943. Mutations of bacteria from virus sensitivity to virus resistance. Genetics, 28: 491-511.

MYERS, N. \& A. H. KNOLL. 2001. The biotic crisis and the future of evolution. Proc. Natl. Acad. Sci. USA, 98:5389-92.

SNIEGOWSKI, P. D. \& R. E. LENSKI. 1995. Mutation and adaptation: The directed mutation controversy in evolutionary perspective. Annual Review of Ecology and Systematics, 26: 553-578.

SNIEGOWSKI, P. D. 2005. Linking mutation to adaptation: overcoming stress at the spa. New Phytologist. 166, 360-362.

SPIESS E. B. 1989. Genes in populations. $2^{\text {nd }}$ ed. Wiley, New York. 780 pp.

WOODRUFF, D. S. 2001. Declines of biomes and biotas and the future of evolution. Proc. Natl. Acad. Sci. USA, 98:5471-5476. 